\title{
Suitability of the South Caribbean Coast of Costa Rica for Reintroduction of the Great Green Macaw Ara ambiguus
}

\author{
Sara Fraixedas 1,2,3* Álvaro Fernández-Llamazares ${ }^{1,2,4}$, Anna Rico², Albert Bach ${ }^{1,2}$, \\ Marta Borrós ${ }^{1}$, Carles Barriocanal' ${ }^{1}$, Martí Boada1 \\ ${ }^{1}$ Institut de Ciència i Tecnologia Ambientals (ICTA), Universitat Autònoma de Barcelona (UAB), Bellaterra \\ (Cerdanyola del Vallès), Spain \\ ${ }^{2}$ La Ceiba Nature Reserve, Punta Uva, Puerto Viejo de Talamanca, Refugio de Vida Silvestre \\ Gandoca-Manzanillo, Caribe Sur, Costa Rica \\ ${ }^{3}$ The Helsinki Lab of Ornithology (HelLO), Finnish Museum of Natural History, University of Helsinki, Helsinki, \\ Finland \\ ${ }^{4}$ Metapopulation Research Group (MRG), Department of Biosciences, University of Helsinki, Helsinki, Finland \\ Email: *sara.fraixedas@helsinki.fi
}

Received 27 June 2014; revised 26 July 2014; accepted 11 August 2014

Copyright (C) 2014 by authors and Scientific Research Publishing Inc.

This work is licensed under the Creative Commons Attribution International License (CC BY). http://creativecommons.org/licenses/by/4.0/

(c) (i) Open Access

\section{Abstract}

The Great Green Macaw Ara ambiguus is an endangered species whose most important food resource and nesting site in Costa Rica is the mountain almond tree Dipteryx panamensis, threatened mainly by deforestation. In this study, we analyse the suitability of reintroducing $A$. ambiguus in the South Caribbean Coast of Costa Rica by examining whether the ecological and socio-cultural conditions required for the reintroduction are met in the area. The methods developed in this work include biological sampling, cartographical analysis and semi-structured interviews, among others. We set La Ceiba Nature Reserve as study unit and starting point of the analysis due both to its conservation status, favouring the potential release of individuals, and its ecosystem representativeness. Our results suggest that the habitat is suitable for reintroduction, with frequent presence of $D$. panamensis in the region, as well as other feeding options and potential nesting sites in the study area. The cartographic study reveals that the species could rely on a forested surface of up to $\mathbf{7 0 0 0}$ hectares, which would be sufficient for sustaining a viable population. As for the socio-cultural analysis, illegal logging and low protective frameworks were identified as the main potential threats for the species. Nevertheless, we perceived positive conservation attitudes among local people and a pro-active commitment of political stakeholders. We conclude that a viable South Caribbean reintroduction of $A$. ambiguus is possible in conjunction with a threat mitigation programme.

\footnotetext{
"Corresponding author.
}

How to cite this paper: Fraixedas, S., Fernández-Llamazares, Á., Rico, A., Bach, A., Borrós, M., Barriocanal, C. and Boada, M. (2014) Suitability of the South Caribbean Coast of Costa Rica for Reintroduction of the Great Green Macaw Ara ambiguus. Natural Resources, 5, 653-665. http://dx.doi.org/10.4236/nr.2014.511057 


\section{Keywords}

\section{Psittacine Conservation, Reintroduction, Threatened Species, Suitability Analysis}

\section{Introduction}

\subsection{Parrot Threats and Conservation Effectiveness}

More than $30 \%$ of the nearly 140 species of parrots (Psittacidae) of the Neotropics are listed as endangered [1] [2]. The combination of habitat loss and illegal parrot trade, the latter particularly worrying in Latin America [3], is considered the most important cause of decline in parrot populations [4] [5].

Reintroduction, defined by IUCN as "an attempt to establish a species in an area which was once part of its historical range, but from which it has been extirpated or become extinct" [6], represents an increasingly used strategy in psittacine bird conservation throughout the world [7]. Several authors recommend the release of individuals solely within the historic range of species as part of the reintroduction process [8] [9]. However, successful reintroduction to the historical range is only possible after identifying and addressing the original causes of population decline [10] [11]. Because there is a broad range of methodologies and assessments that can be potentially employed in reintroduction programmes [7], the use of reintroductions as a tool for conservation certainly needs further research and improvement to ensure the chances of success (based on King's et al. definition of "success" [12]). In this sense, it is crucial to update and refine the reintroduction process based on the lessons learned from different case studies (e.g., [7]).

Despite the several unsuccessful parrot reintroduction attempts (e.g., [8] [13]), there are various examples in which viable populations of many species have been well-established (e.g., [14] [15]), yet not always deliberately [16] [17]. In the case of macaws, there are quite a few examples of reintroductions undertaken in Central American countries [18]. For instance, ongoing releases of Scarlet Macaw Ara macao and Great Green Macaw A. ambiguus in Costa Rica have resulted in high survival rates [19]. In Costa Rica, numerous years of experience in reintroductions and a rate success of more than $70 \%$ after 2 - 3 years [18] suggest a potential long-term success.

\subsection{Ecological Associations}

Within the context of the so-called parrot conservation crisis is A. ambiguus, an endangered parrot whose distribution area in Costa Rica has been reduced by up to $90 \%$ mostly because of deforestation [20]-[23]. This alarming situation calls for urgent conservation projects for the species and its habitat. A. ambiguus is one of the two macaw species found in Costa Rica and the second biggest parrot of the New World [24] [25]. It inhabits the canopy of the humid and wet lowland tropical rainforests, flying over great distances during the non-breeding season to obtain food [26] [27]. In Costa Rica, the fruit seeds of the mountain almond tree Dipteryx panamensis represent the main component of its diet [28] [29], even though different diet composition has been reported in other countries (e.g., Ecuador [30]). Studies on A. ambiguus nesting indicate that the species chooses to nest in tree hollows of $D$. panamensis in over $90 \%$ of cases [31] [32]. In this sense, this tree can be considered as the most important nesting and food resource for the species in the country [32] [33]. D. panamensis is an emergent tree of the tropical rainforest and is largely distributed along the Caribbean Coast of Costa Rica [25] [34].

A decrease in the international price of cattle and reforestation state policies made incentives for livestock being replaced by new incentives for forest management during the mid-1980s [24]. Further modernization of sawmills and changes in industry increased forest degradation, and high commercial value of $D$. panamensis encouraged indiscriminate felling [25] until it became a threatened species in 2005 [35] [36]. The substantial reduction of the nesting area of A. ambiguus in Costa Rica motivated a total ban on the exploitation of $D$. panamensis that is still effective today [22] [37].

This study reports on how the suitability of a reintroduction can be empirically assessed for an endangered species. Based on some of the criteria for parrot reintroductions [4], including improvement of the causes originating the population decline and careful evaluation of potential release sites [7], we analysed the suitability of reintroducing A. ambiguus in the South Caribbean Coast of Costa Rica within the historical distribution range of 
the species. We set La Ceiba Nature Reserve as study unit and starting point of the analysis due both to its conservation status, favouring the potential release of individuals, and its ecosystem representativeness, and examined the ecological and socio-cultural conditions for reintroduction of the species. As a second step and related to A. ambiguus conservation, we aim to help establishing a scientific basis for its reintroduction in the South Caribbean Coast of Costa Rica, highlighting the importance of suitability studies as means of maximizing the chances of success of a reintroduction.

\section{Methods}

\subsection{Study Area}

The study area is the South Caribbean Coast of Costa Rica, which is restricted to the coastal region between the southern extreme of the Cahuita National Park and the village of Gandoca, bordering Panama. As for the study unit, La Ceiba Nature Reserve is composed of 42 ha and is located within the large Gandoca-Manzanillo Wildlife National Refuge (Refugio de Vida Silvestre Gandoca-Manzanillo; hereinafter REGAMA), extending from Puerto Viejo to the Panamanian border (see Figure 1).

\subsection{Research Schedule}

All the fieldwork was carried out from September to November 2010, corresponding with the start of the fruiting season of D. panamensis (from December to February [24]).

\subsection{Sampling of $D$, panamensis at La Ceiba}

All the almond trees were sampled in the reserve to assess the availability of both food and nesting sites for $A$. ambiguus. The sampling was performed in plots of $20 \times 30 \mathrm{~m}$ processed with MiraMon program [38] [39], a

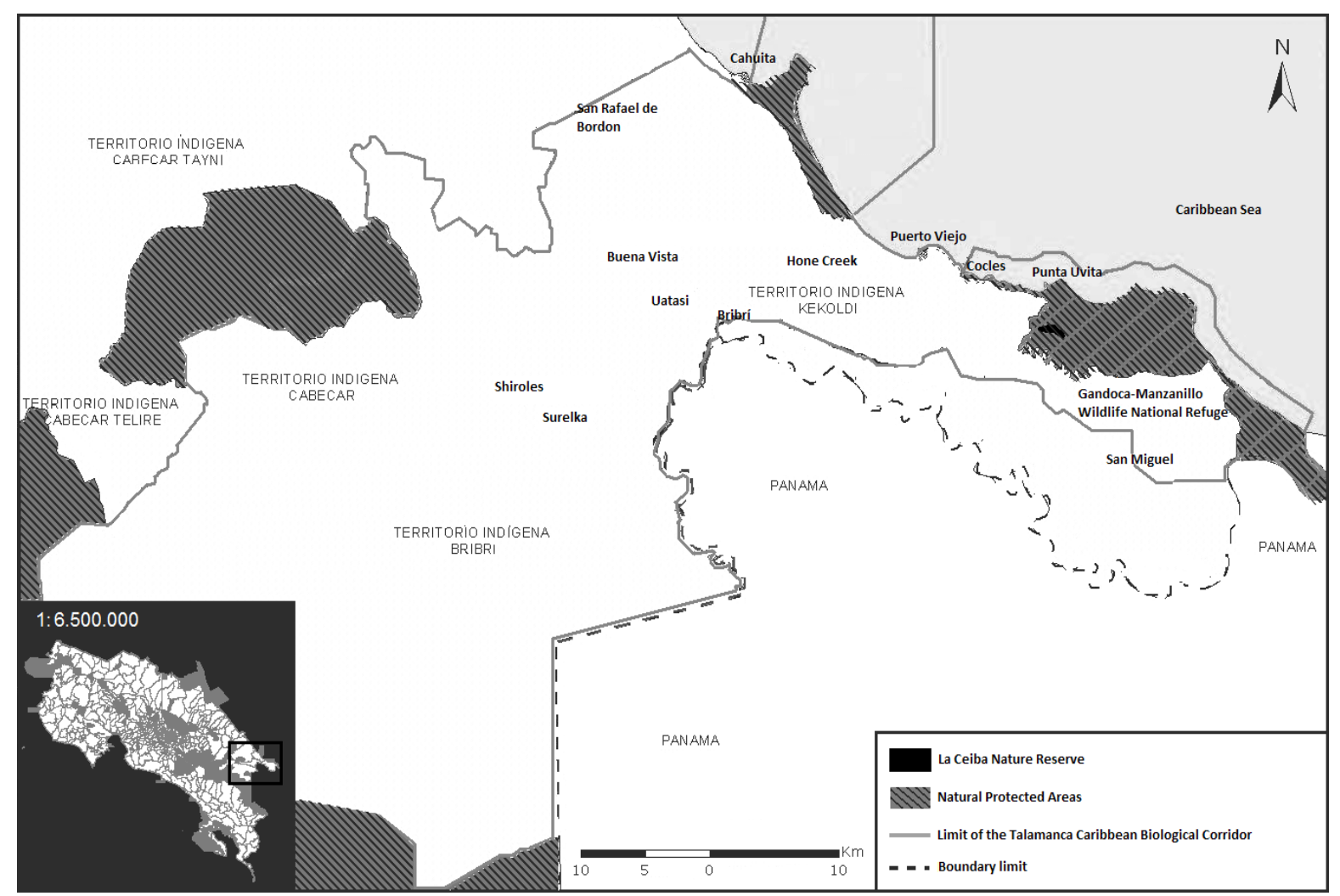

Figure 1. Study area and location of La Ceiba Nature Reserve in the Gandoca-Manzanillo Wildlife National Refuge (Refugio de Vida Silvestre Gandoca-Manzanillo, REGAMA). Source and author: Association of the Talamanca Caribbean Biological Corridor, Asociación Corredor Biológico Talamanca-Caribe, ACBTC. 
Geographic Information System (GIS) and Remote Sensing (RS) software [40]. As a result of the division of the 42 ha of the reserve, we obtained a total of 836 plots that were located in the field using a GPS device.

The diameter of each tree was measured using the DBH (Diameter at Breast Height) method. According to Madriz-Vargas [24], individuals with an average DBH higher than $1.24 \mathrm{~m}$ are likely to have suitable cavities for A. ambiguus nesting. Cavities were located, registered and classified into two categories, suitable and unsuitable. Suitability was defined following the study of Brenes et al. [41], in which cavities exceeding $40 \mathrm{~cm}$ in diameter are considered as suitable for $A$. ambiguus nesting. This variable was estimated visually with binoculars when complete observation was possible. We only made observations from the ground due to the lack of equipment for climbing trees.

We also calculated the percentage of mature trees to estimate the food resource potential of the reserve. This was done by calculating the percentage of seeds and/or seedlings nearby the identified specimens.

\subsection{Partial Sampling of Other Forage Species}

A partial sampling of other forage species was also carried out in the reserve to verify that A. ambiguus had other feeding options when the almond trees were not fruiting. For this purpose, four species were chosen in view of their dietary complement to D. panamensis: the barrigona palm [23] Iriartea deltoidea, the andiroba [24] Carapa guianensis, the yellow laurel [26] Cordia megalantha, and the golden fruit [42] Virola koschnyi.

We conducted a preliminary random sampling of the first 50 plots of $20 \times 30 \mathrm{~m}$. The number of trees of each species was treated as a random variable with a Poisson distribution $\mathrm{X} \sim$ Pois $(\lambda)$ and a parameter $\lambda>0$. The estimate of $\lambda$ corresponds to the rate of trees of a single species per plot from $n$ plots. The results of this preliminary sampling allowed us determining that 304 plots was the minimum number of plots to sample for a confidence level $(\gamma)$ of 0.90 and an error of 0.045 trees/plot (i.e. a relative error of 28\%; [43]).

We used the same plots and protocol as those established for the sampling of $D$. panamensis. The selection of the plots to sample was made through the statistics software developed by the Office for Research Development and Education of the University of Colorado [44]. For C. guianensis and V. koschnyi, only individuals with diameter exceeding $30 \mathrm{~cm}$ were considered. For $C$. megalantha, a minimum diameter of $20 \mathrm{~cm}$ was determined, while for the I. deltoidea only individuals over $10 \mathrm{~m}$ in height were taken into account. Preliminary field observations in the first 50 plots enabled to relate these values to the age at which the species begin to bear fruit. In the case of I. deltoidea, the height was considered instead of the diameter, as not all palm trees experience a proportional growth in their trunk related to age. Densities for the total surface of the reserve were extrapolated from data collected in the random sampling for each of the four species, with a $\gamma$ of 0.95 so that we could finally estimate the abundance of the selected forage species in the territory.

\subsection{Competition/Predation Study}

This survey was conducted to determine the species that could exert some pressure on A. ambiguus in the study area. A first review permitted us to rule out the possibility of any predators of adult individuals (as few records of predation on adult macaws have been reported, probably because of their size and flight [45] [46]) and focus only on competing species and egg and chick predators. Competing species were regarded as those that could exert some pressure on A. ambiguus both in terms of food and nesting, i.e. individuals feeding on fruits of $D$. panamensis or nesting in its cavities. Nesting predators were defined as species feeding on eggs or chicks of $A$. ambiguus in almond tree cavities.

The study was performed by observing the fauna associated with a specimen of $D$. panamensis located in a wooded area of Punta Uva (see Figure 1). We selected this particular tree because of its size and easy visualization of the top from different viewing angles. Observations were made once a week and we scheduled three daily observation intervals of 15 minutes, yielding a total of 33 sampling periods.

\subsection{Connectivity Study}

We developed a connectivity study of the reserve with nearby natural areas to find out: a) how present mature almond trees were outside the reserve to provide food and shelter to A. ambiguus' individuals; and b) whether a continuous forest area sufficiently large to sustain an A. ambiguus population existed. The first part of the study was evaluated through an informative campaign carried out during October to establish contact with the local people who might know D. panamensis locations in the villages of Bribrí, Puerto Viejo, Gandoca and Man- 
zanillo (see Figure 1). The distribution of informative leaflets and subsequent contact with local peoples helped us in the location, marking and characterization of $D$. panamensis in the area, following the same protocol developed for the sampling in the reserve. To answer the second question, we performed a cartographic analysis of the land use in the study area. We put special focus on vegetation and computed the area covered by tropical rainforest found around the reserve. The processing of the cartographic data was developed using MiraMon program [38] [39].

\subsection{Socio-Cultural Approach to the Natural History of A. ambiguus in the Region}

A socio-cultural approach to the natural history of A. ambiguus was required to establish the original causes of its decline in the study area and to analyse the socio-cultural aspects that could affect a hypothetical reintroduction. These results might help determining whether the previous causes of extinction have been removed when implementing a reintroduction programme. Research design involved data collection at local, regional and national levels. We used a number of techniques common to social science research, mainly including semi-structured interviews, participant observation and document analysis.

We arranged twenty semi-structured interviews with experts and local people who were familiar with the natural history of the species. To capture variation in local perceptions regarding conservation initiatives, we interviewed: a) men $(n=13)$ and women $(n=7)$; b) subjects with different political views and roles; and c) subjects with various levels of participation in local conservation initiatives. Interviews lasted from 20 minutes to more than 1 hour. The sample was composed of naturalist guides, graduates in Anthropology, Environmental Sciences and Zoology, conservationists, indigenous representatives, local activists and researchers. The involved organisations were institutions such as the Tropical Science Centre (Centro Científico Tropical, CCT), environmental associations as ACBTC or the Kèköldi Wakka Köneke Indigenous Association (Asociación Indígena Kèköldi Wakka Köneke), and the regional delegation of the Ministry of Environment, Energy and Telecommunications (Ministerio de Medio Ambiente, Energía y Telecomunicaciones; hereinafter MINAET). Semi-structured interviews were chosen among other survey techniques because they are useful for addressing certain topics while allowing for more interaction than a formal questionnaire [47]. During interviews, respondents were asked to assess, according to their perception, the suitability of the species reintroduction, the current state and legal protective framework of the habitat, and the levels of environmental awareness in the region. At the end of the interviews, as a mode of conclusion, we read a list of statements concerning: a) several potential effects of an eventual reintroduction programme of A. ambiguus; and b) the possibilities of success of the reintroduction of $A$. ambiguus in the area. We asked informants whether they agreed or not with each statement.

Furthermore, we took part in regular local activities and meetings (e.g., indigenous assemblies in Bribrí, working meetings with the reserve board team members, local demonstrations, reintroductions of animals into the wild along with the Jaguar Rescue Center, etc.) where same topics as those included in the semi-structured interviews were discussed. Participant observation involves the researcher establishing rapport in a social setting while removing him or herself from cultural immersion so that they can retain an objective position [47]. This technique allowed us to observe not only the everyday life of the local people in the area (with particular regard to conservation attitudes and values), but also understanding processes within and between institutions involved in the implementation of conservation initiatives, with a special focus on decision-making among stakeholders. Document analysis was also used to gather relevant information through the analysis of key documents (including reports, project plans, maps and environmental evaluation assessments). This analysis provided specific information on the conservation schemes of REGAMA.

\subsection{Data Analysis and Statistical Processing}

Statistical tests were carried out to validate hypotheses and verify statistical significance. In all cases, a hypothesis test with unknown variance $\left(\sigma^{2}\right)$ was applied using the $t$-statistic whose distribution is Student's $t$-distribution with $n-1 \mathrm{df}$ when $\mu=\mu_{0}$. The hypothesis tests were performed using the predictive analytics software PASW Statistics 17 [48].

\section{Results}

\subsection{Sampling of $D$. panamensis at La Ceiba}

A total of 46 specimens of $D$. panamensis were counted, which resulted in a density of 1.1 ind./ha. The distribu- 
tion of the species was regular for all the sampled area (see Figure 2) and the average DBH was $1.51 \pm 0.15 \mathrm{~m}$ $(n=46 ; s=0.504 ; \gamma=95 \%)$. This value was significantly higher than $1.24 \mathrm{~m}(n=46 ; t=3.63 ; P<0.001)$, being $71.7 \%$ of the sampled trees potential holders of suitable cavities for $A$. ambiguus nesting.

Cavities were observed in $50.0 \%$ of the sampled trees, $47.8 \%$ of which had only one cavity. The suitability could only be checked in 11 cavities, 7 of which were considered as suitable for $A$. ambiguus nests. The average DBH of the almond trees with cavities was $1.63 \pm 0.15 \mathrm{~m}(n=23 ; s=0.355 ; \gamma=95 \%)$.

Regarding the presence of seeds and seedlings, $41.3 \%$ of the counted specimens were surrounded by seeds, whereas $45.7 \%$ had seedlings nearby. The percentage of mature almond trees in the reserve was $65.2 \%$.

\subsection{Partial Sampling of Other Forage Species}

The abundance estimate for the selected forage species is shown in Table 1. I. deltoidea was the most abundant species in the reserve, followed by $V$. koschnyi.

\subsection{Competition/Predation Study}

A total of two mammal species and eight bird species were found at the observation point. For reptiles, snakes and ctenosaurs (both nesting predators [49] [50]) were unfortunately ruled out because identification was not possible from the ground.

Even though various mammal species can also act as egg and chick predators (e.g., rats, tayras, felids [45] [49]), only the Central American Spider Monkey, Ateles geoffroyi and the White-faced Capuchin, Cebus capucinus could be detected (a total of three times during the observation intervals). Toucans (mainly the Keel-billed Toucan, Ramphastos sulfuratus and the Chestnut-mandibled Toucan, $R$. swainsonii were observed) are known to

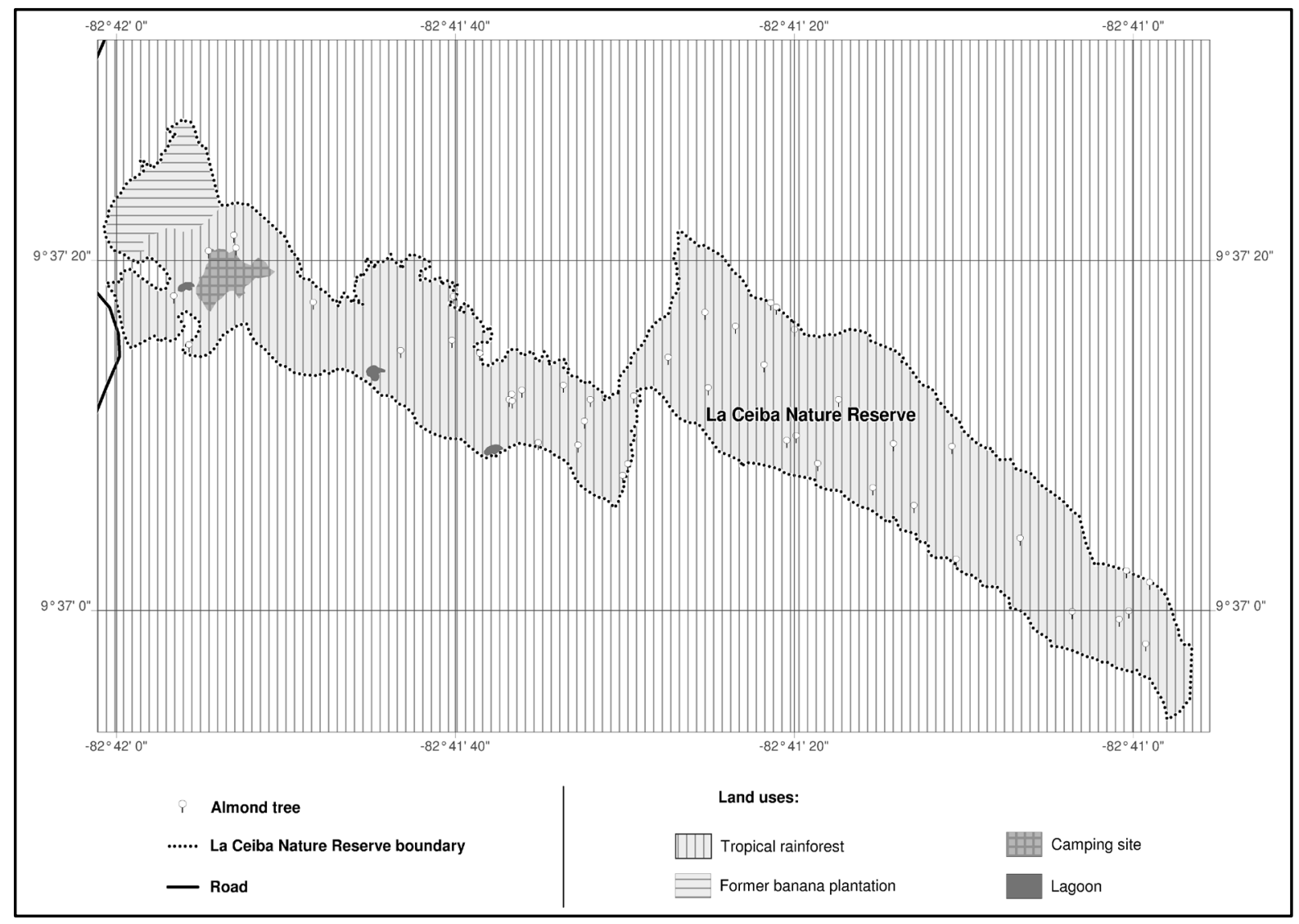

Figure 2. Land use at La Ceiba Nature Reserve along with the number and distribution of $D$. panamensis individuals. Source: own elaboration based on shapefiles previously generated by the managers of the reserve and processed afterwards with MiraMon program. Author: Borrós, M. 
Table 1. Results from the random sampling of forage species and the following extrapolation for the entire reserve. Densities for the total surface of the reserve are extrapolated from data collected in the random sampling for each of the four forage species.

\begin{tabular}{|c|c|c|c|c|}
\hline \multirow{2}{*}{ Variables } & \multicolumn{4}{|c|}{ Forage species } \\
\hline & C. guianensis & C. megalantha & I. deltoidea & V. koschnyi \\
\hline Total number of individuals in the random ampling & 53 & 29 & 278 & 111 \\
\hline Error associated with the total number of individuals & 16 & 11 & 58 & 26 \\
\hline Average (ind./plot) & 0.17 & 0.10 & 0.91 & 0.37 \\
\hline Standard deviation (s) & 0.465 & 0.315 & 1.685 & 0.749 \\
\hline Error associated with the sampling & 0.052 & 0.035 & 0.189 & 0.084 \\
\hline Total number of individuals for the entire reserve & 142 & 84 & 761 & 309 \\
\hline Error associated with the total number of individuals & 44 & 30 & 158 & 70 \\
\hline Reserve density (ind./ha) & 3.4 & 2.0 & 18.1 & 7.4 \\
\hline Error associated with the reserve density & 1.0 & 0.7 & 3.8 & 1.7 \\
\hline Percentage of error for the entire reserve (\%) & 31 & 35 & 21 & 23 \\
\hline
\end{tabular}

a. Average percentage of relative error $(\%)=28$.

be nest predators of macaws [49]. In connection with competing species, some parrot and toucan species can also nest in the cavities of $D$. panamensis, but neither of them shows any pattern of preference for the tree [51]. The Mealy Amazon, Amazona farinosa was found once eating the seeds of $D$. panamensis, but again the species does not show a preferential pattern for it [51].

\subsection{Connectivity Study}

The contact with 16 farmers and citizens who were interested in the survey resulted in a total of 20 visits to privately-owned properties and communal areas with presence of $D$. panamensis. The sampling in the adjoining areas allowed the registration of 85 almond trees with an average DBH of $1.18 \pm 0.15 \mathrm{~m}(n=85 ; s=0.710 ; \gamma=$ 95\%), showing that D. panamensis is a frequent species in the South Caribbean forests (see Figure 3). Among the total amount of identified almond trees, 57 had a diameter over $1.24 \mathrm{~m}$. The addition of these specimens to the 33 found in the reserve resulted in 90 individuals suitable for the nesting of $A$. ambiguus with an average $\mathrm{DBH}$ of $1.68 \pm 0.08 \mathrm{~m}(n=90 ; s=0.396 ; \gamma=95 \%)$, a value significantly higher than $1.24 \mathrm{~m}(n=90 ; t=10.53$; $P<0.001$ ). Cavities were observed in $22.4 \%$ of the sampled trees, $63.2 \%$ of which had only one cavity. Ten over 31 cavities were considered as suitable for $A$. ambiguus nests. The average DBH of the almond trees with cavities was $1.18 \pm 0.32 \mathrm{~m}(n=19 ; s=0.710 ; \gamma=95 \%)$.

The results of the cartographic analysis show that a continuum of tropical rainforest of more than 7000 ha exists along the study area and surrounding the reserve, covering $80.28 \%$ of the surveyed territory (see Figure 3 ).

\subsection{Socio-Cultural Approach to the History of A. ambiguus in the Region}

The results of the semi-structured interviews suggested an evident conservationist attitude in the Talamanca province, with many positive feedbacks received about the possibilities of reintroduction (see Table 2). For example, from our interviews, it was clear that the majority of the informants acknowledged that the reintroduction would be positive for the region (85\%), particularly for the development of ecotourism programmes. However, most of the informants also recognized that illegal felling persisted in the area, even if these processes had lowered considerably since the 1990s, when the bulk of the species decline took place. A conservation agent from REGAMA stated "What if we get the Great Green Macaw reintroduced and it disappears? It is not just about liberating the birds; it is also a matter of assuring that the population can be sustained over time”. Moreover, $45 \%$ of the informants considered current levels of illegal felling hampering the success of an eventual reintroduction in the area. According to $60 \%$ of the interviewees, increasingly stronger legal frameworks to protect natural areas and the development of conservation incentives, such as the Payment for Ecosystem Services, 


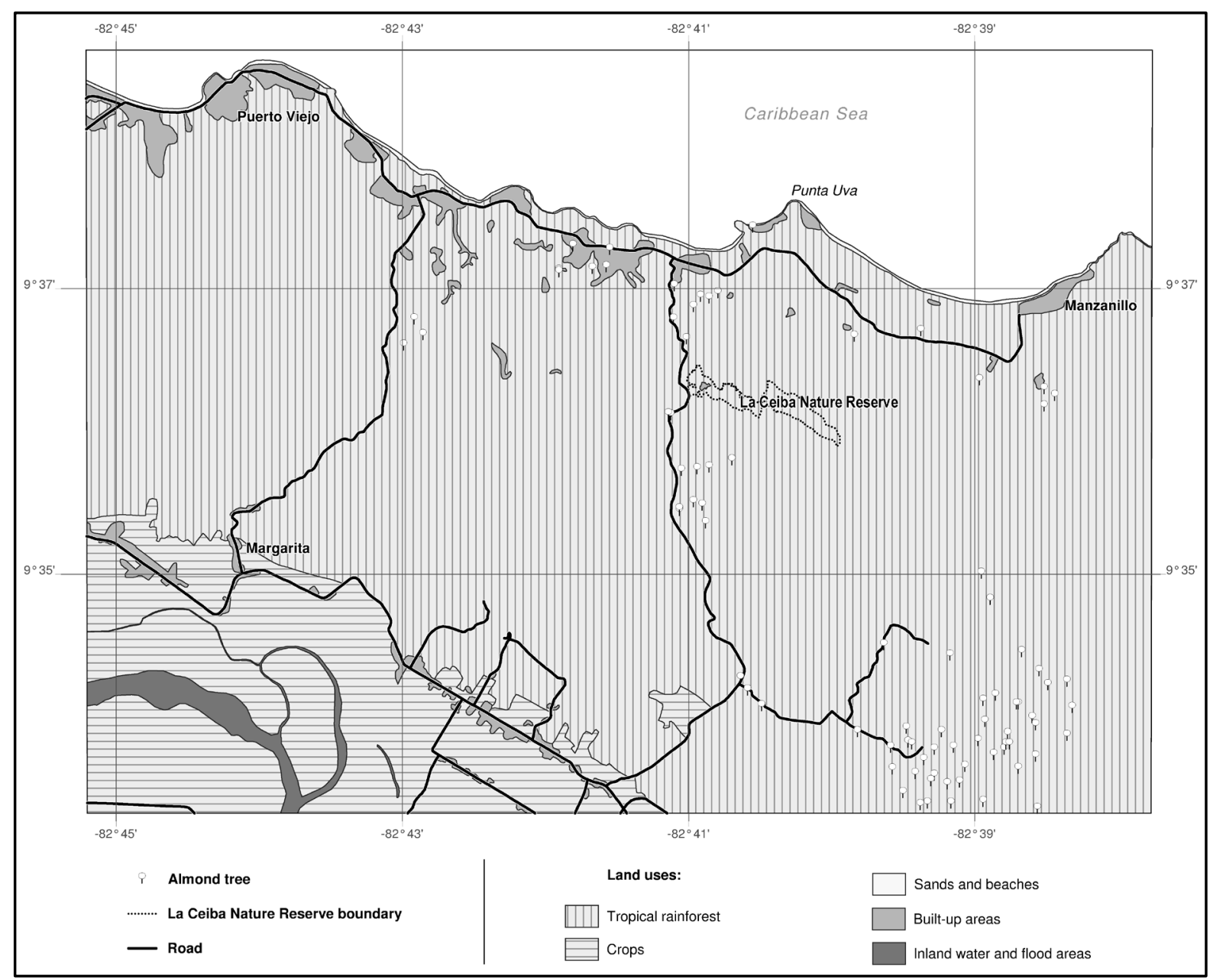

Figure 3. Land use in the study area along with the sampling of $D$. panamensis as a result of the connectivity study. Source: own elaboration based on satellite images from Digital Globe Company (2010) and generated with MiraMon program. Author: Borrós, M.

Table 2. Results from the semi-structured interviews. The table presents the list of statements concerning: a) several potential effects of an eventual reintroduction programme of A. ambiguus in the area; and b) the possibilities of success of the reintroduction of A. ambiguus in the South Caribbean. Answers are based on informants' own perceptions and experiences.

Question: Do you agree with the idea that:
The reintroduction of A. ambiguus would be positive for the region? $(n=20)^{\mathrm{a}}$
The study area is prepared for the reintroduction of A. ambiguus?
An environmental awareness programme in the region should be carried
out prior to the reintroduction of the species?
Local people show conservation attitudes that would benefit an eventual reintroduction?
The legal protective framework of the habitat is strong enough to implement the reintroduction?

a. Cells represent the percentage of informants that agree with the statement.

have strengthened local people's perceptions towards conservation, even if more efforts are evidently needed to improve on this direction. A local leader from Puerto Viejo de Talamanca said "The reintroduction will surely 
engage local people and this will have a very positive impact for conservation and education in the region". Additionally, the political stakeholders interviewed demonstrated interest on enforcing the legal status of REGAMA to fight poor management and control over natural resources and improve conservation outcomes, particularly through the development of projects such as a potential A. ambiguus reintroduction.

Local informants indicated that A. ambiguus was a resident species in the area of study, especially in REGAMA, until one decade ago. The abundance of $D$. panamensis made possible not only its nesting but also its survival. However, from the 1980s, a number of human impacts began to take place, which probably led to the decrease of the species' population in the region. These human impacts were related to the illegal felling of $D$. panamensis, which caused the disappearance of many nests and consequently a direct impact on the reproduction of the population, the killing for pleasure of many individuals of A. ambiguus as well as for its meat, appreciated in some localities as San Miguel or Gandoca, and finally the poaching of chicks for further trade and distribution in Europe and North America.

All these impacts led to a reduction in the number of individuals until the year 2000, where only 12 specimens were reported around REGAMA. After few years, a couple of $A$. ambiguus was seen again in the area and its sighting was recorded several times from 2005 in the Ornithological Observatory of the Kèköldi Indigenous Reserve, the villages of San Miguel and Gandoca, and La Ceiba Nature Reserve. In late 2008, one individual of the couple was killed with a firearm by a resident of San Miguel. From that date to 2010 there was only a single specimen in REGAMA (i.e. only known South Caribbean population).

\section{Discussion}

Although documentation on reintroduction processes and outcomes has improved in the last years [52] [53], most of the reintroduction research is nowadays still retrospective. Indeed, the question of determining success in reintroduction has been the subject of inconclusive debate (e.g., [54]), and researchers and conservation managers still lack of adequate understanding on how to determine inherent technical and biological limitations of reintroductions. In this study, we present a methodology to assess the suitability for reintroduction of an endangered species. Identifying the factors responsible for the decline in A. ambiguus population is crucial when examining the requirements of the species, as also the disappearance or partial correction of the causes attributed to its extinction in the region, essential for individuals' reestablishment. Besides the ecological considerations, we made a special focus on socio-cultural variables, as there are still meagre works covering local attitudes and concerns towards reintroductions. We believe the approach used here-in concordance with IUCN [6] and Collar [52] — can contribute to the study of parrot reintroductions.

Given the dependence of A. ambiguus on D. panamensis, the presence and abundance of the tree in the territory can be considered as the principal parameter of habitat quality for the species. According to the categories of rarity proposed by Rabinowitz et al. [55], we determined that $D$. panamensis was relatively frequent on a local level. This is based on the comparison between the density found in the reserve (1.1 ind./ha) with the density estimated to the rest of Costa Rica (2.0 ind./ha [56] [57]). Two other relevant aspects must be taken into account: a) the great quantity of fruit produced by $D$. panamensis; and b) the high percentage of mature trees found in the reserve. Both factors are good indicators of the potential of the reserve as food reservoir for the species, being complemented by the presence of other forage species also abundant in the reserve. Regarding the nesting possibilities and considering the number of cavities as well as the diameter of the marked individuals found both in the reserve and in the connectivity study, we can confirm there are appropriate nesting sites in the study area. Because a high percentage of individuals of $D$. panamensis had an average DBH greater than $1.24 \mathrm{~m}$, we deduced that the number of existing cavities is greater than the ones reported in this study. In addition, lack of climbing equipment made not possible to explore other potential nesting sites. Lastly, the distribution of the sampled individuals found in the connectivity study and the observed forest continuity of the surveyed area verify that the presence of $D$. panamensis is frequent in the region. All these factors indicate habitat suitability for A. ambiguus not only on a local but also on a large scale. On the other hand, although a few records of competitor and predator species were registered, which would mean little effect on the survival rates of A. ambiguus, we acknowledge the predation results might be biased by the fact that some macaw predators could not be included in the study.

The nesting habits of A. ambiguus, such as the careful selection of the cavities and the aggregated nesting patterns, are largely unknown [58]. Indeed, the relatively scarce information on the reproductive biology of the species, coupled with the absence of long-term datasets on the former population or the deforestation in the area, 
made the suitability of a reintroduction difficult to predict. Nevertheless, according to the cartographic analysis, A. ambiguus could rely on a surface of up to 7000 ha of reproductive area in the South Caribbean, which would be sufficient for sustaining a viable population [31] as it existed in the past. In a socio-cultural context, the results of the semi-structured interviews evidenced conservationist and positive attitudes towards a possible reintroduction in the area. However, many informants recognized that the causes leading to the decline of the former population of A. ambiguus in the region might not have been totally reversed. Even considering that all of them agreed that the situation has clearly improved since the 1990s, on the basis of participant observation, the accumulated information obtained from the interviews and document analysis, we recommend the performance of a programme of corrective measures both prior and synchronously to the reintroduction of the species. These measures would be needed to: a) raise the environmental awareness of the local people; b) prevent illegal felling in the forests of the region; and c) strengthen the legal protective framework of the species habitat. A rigorous and place-specific awareness programme on these directions, to be executed by MINAET and developed in cooperation with the local institutions (e.g., The Ara Project), would give a hypothetical reintroduction an unusual breath and greater chances of success in a context of increasing environmental consciousness. The fact that the local people do possess some institutional assets and count on the pro-active commitment of the political stakeholders of the region provides a valuable basis for an eventual attempt of reintroduction.

A study by Vaughan et al. [59] on the conservation of the Scarlet Macaw in the Central Pacific, Costa Rica, showed that collaborative management practices by local stakeholders and governmental authorities had a clearly positive impact on the recovery of wild populations, increasing the reproductive rates. These management practices were coordinated through a local conservation organisation created to establish an environmental education programme as well as nest constructions, networking among stakeholders, and nest protection. We recommend the creation of such an organisation when local authorities face an A. ambiguus reintroduction in the South Caribbean, Costa Rica. Educational programmes fostering national pride to promote the conservation of certain species, particularly within limited areas such as Caribbean communities, have demonstrated great success and are a crucial element of reintroduction programmes [11] [60]. Consequently, suitability remains conditional on a series of corrective measures that should be carried out to ensure a successful reintroduction. No conservation results can be achieved without long-term protection of the habitat, local environmental awareness, and a real commitment of policy-makers towards conservation.

\section{Conclusion}

Increased awareness of reintroduction as a viable conservation option relies directly upon the success of reintroduction programs and this can only be improved through greater emphasis on fieldwork-based empirical research. Despite the importance of the topic for conservation research, the absence of canonical standards on pursuing analyses of reintroduction suitability hampers the possibilities of successfully achieving such goal. Moreover, the frequent knowledge lacunae on individual species' needs and biological requirements (e.g., the still unanswered reproductive biology of A. ambiguus) compel researchers to refine our approaches to empirically assess reintroduction viability. Along these lines, the methodology applied in the present work, integrating both ecological and socio-cultural factors into viability analysis, can be considered as a potentially useful tool to ensure the success of reintroduction programs and therefore, it can set the foundations of further investigations to be pursued in the field of conservation science.

\section{Acknowledgements}

The authors wish to thank J. Belmonte, O. Chassot, R. Delgado, A. Lehikoinen, G. Monge-Arias, P. Vangoidsenhoven, K. Välimäki and C. Vives for their help in manuscript preparation, as well as La Ceiba Nature Reserve for technical support. We gratefully acknowledge the financial support and generosity of the Ethnoecology Laboratory (http://icta.uab.cat/Etnoecologia) and the Global Change and Conservation Group (http://gcc.it.helsinki.fi), without which the present study could not have been brought to completion. This research was funded by a grant of the Maj and Tor Nessling Foundation to S. F. and a fellowship of the Finnish Centre for International Mobility (CIMO) to Á. F.-Ll.

\section{References}

[1] Collar, N.J. and Juniper, A.T. (1992) Dimensions and Causes of the Parrot Conservation Crisis. In: Beissinger, S.R. 
and Snyder, N.F.R., Eds., New World Parrots in Crisis: Solutions from Conservation Biology, Smithsonian Institution Press, Washington DC, 1-24.

[2] BirdLife International (2013) Birds on the IUCN Red List. http://www.birdlife.org//worldwide/science

[3] BirdLife International (2008) The Illegal Parrot Trade Remains a Problem in Latin America. http://www.birdlife.org/datazone/sowb/casestudy/165

[4] Snyder, N.F.R., McGowan, P., Gilardi, J. and Grajal, A. (2000) Parrots: Status, Survey and Conservation Action Plan. International Union for Conservation of Nature (IUCN), Washington DC.

[5] Wiley, J.W., Gnam, R.S., Koenig, S.E., Dornelly, A., Gálvez, X., Bradley, P.E., White, T., Zamore, M., Reillo, P.R. and Anthony, D. (2004) Status and Conservation of the Family Psittacidae in the West Indies. Journal of Caribbean Ornithology, 17, 94-154.

[6] IUCN (1998) IUCN Guidelines for Reintroductions. IUCN/SSC Reintroduction Specialist Group, IUCN, Gland.

[7] White, T.H., Collar, N.J., Moorhouse, R.J., Sanz, V., Stolen, E.D. and Brightsmith, D.J. (2012) Psittacine Reintroductions: Common Denominators of Success. Biological Conservation, 148, 106-115. http://dx.doi.org/ 10.1016/j.biocon.2012.01.044

[8] Snyder, N.F.R., Koenig, S.E., Koschmann, J., Snyder, H.A. and Johnson, T.B. (1994) Thick-Billed Parrot Releases in Arizona. Condor, 96, 845-862. http://dx.doi.org/10.2307/1369097

[9] Enkerlin-Hoeflich, E.C. (2002) Study and Conservation of Thick-Billed and Maroon-Fronted Parrots in Mexico. Proceedings of the 5th International Parrot Convention, Tenerife, 18-21 September 2002, 43-62.

[10] Primack, R.B. (1993) Essentials of Conservation Biology. Sinauer Associates, Inc., Sunderland.

[11] Sanz, V. and Grajal, A. (1998) Successful Reintroduction of Captive-Raised Yellow-Shouldered Amazon Parrots on Margarita Island, Venezuela. Conservation Biology, 12, 430-441. http://dx.doi.org/ 10.1111/j.1523-1739.1998.96261.x

[12] King, T., Chamberlan, C. and Courage, A. (2012) Assessing Reintroduction Success in Long-Lived Primates through Population Viability Analysis: Western Lowland Gorillas (Gorilla gorillagorilla) in Central Africa. Oryx, 48, $294-303$. http://dx.doi.org/10.1017/S0030605312001391

[13] Wiley, J.W., Snyder, N.F.R. and Gnam, R.S. (1992) Reintroduction as a Conservation Strategy for Parrots. In: Snyder, N.F.R. and Beissinger, S.R., Eds., New World Parrots in Crisis: Solutions from Conservation Biology, Smithsonian Institution Press, Washington DC, 38-47.

[14] Robertson, C.J.R., Hyvönen, P., Fraser, M.J. and Pickard, C.R. (2007) Atlas of Bird Distribution in New Zealand, 1999-2004. Ornithological Society of New Zealand, Wellington.

[15] Ortiz-Catedral, L., Kearvell, J. and Brunton, D.H. (2010) Re-Introduction of Captive-Bred Malherbe’s Parakeet to Maud Island, Marlborough Sounds, New Zealand. In: Soorae, P.S., Ed., Global Re-Introduction Perspectives: Additional Case-Studies from around the Globe, IUCN/SSC Re-Introduction Specialist Group, Abu Dhabi, 151-154.

[16] Cassey, P., Blackburn, T.M., Russell, G.J., Jones, K.E. and Lockwood, J.L. (2004) Influences on the Transport and Establishment of Exotic Bird Species: An Analysis of the Parrots (Psittaciformes) of the World. Global Change Biology, 10, 417-426. http://dx.doi.org/ 10.1111/j.1529-8817.2003.00748.x

[17] Carrete, M. and Tella, J.L. (2008) Wild-Bird Trade and Exotic Invasions: A New Link of Conservation Concern? Frontiers in Ecology and the Environment, 6, 207-211. http://dx.doi.org/10.1890/070075

[18] Figueras, R.R. (2014) Scarlet Macaw Ara macao cyanoptera Conservation Programme in Mexico. International Zoo Yearbook, 48, 48-60. http://dx.doi.org/ 10.1111/izy.12049

[19] The Ara Project (2013) The Ara Project: Release Sites. http://thearaproject.org/

[20] Chassot, O., Monge-Arias, G., Powell, G. and Palminteri, S. (2001) Lapa Verde, víCtima del Manejo Forestal Insostenible. Ciencias Ambientales, 21, 60-69.

[21] Chassot, O., Monge-Arias, G., Alemán, U., Powell, G. and Palminteri, S. (2002) Lapa Verde, Estable pero Inviable. Ciencias Ambientales, 24, 18-23.

[22] Chassot, O., Monge-Arias, G. and Powell, G. (2006) Biología de la Conservación de la Lapa Verde (1994-2006), 12 Años de Experiencia. Centro Científico Tropical (CCT), San José.

[23] Powell, G., Wright, P., Alemán, U., Guindón, C., Palminteri, S. and Bjork, R. (1999) Resultados y Recomendaciones para la Conservación de la Lapa Verde (Ara ambigua) en Costa Rica. CCT, San José.

[24] Madriz-Vargas, B. (2004) Relación de Dependencia Directa entre Ara ambigua y Dipteryx panamensis. Comisión Interna del Sistema Nacional de Áreas de Conservación (SINAC), San José.

[25] Villate, R., Canet-Dessanti, L., Chassot, O. and Monge-Arias, G. (2009) El Corredor Biológico San Juan—La Selva: Una estrategia exitosa de conservación. CCT, San José.

[26] Chassot, O. and Monge-Arias, G. (2008) Experiencia Binacional para la Conservación de la Lapa Verde, Nicaragua- 
Costa Rica 2000-2008. CCT, San José.

[27] Stiles, G. and Skutch, A. (1989) Guía de Aves de Costa Rica. Cornell University Press, New York.

[28] Bird Life International (2014) Species Factsheet: Ara ambiguus. http://www.birdlife.org/datazone/speciesfactsheet.php?id=1550

[29] Tracy Aviary (2012) Great Green Macaw. http://www.tracyaviary.org/development-v2/pdf/Great\%20Green\%20Macaw.pdf

[30] Lopez-Lanus, B., Laverde, O., Omena, R. and Olarte, L.G. (1999) New Records of Pale-Footed Swallow Notiochelidon flavipes in the Cordillera Central, Colombia. Cotinga, 12, 72.

[31] INBio (2004) Ara ambiguus (Bechstein, 1811): Lapa verde, Guacamayo Verde Mayor. Instituto Nacional de Biodiversidad (INBio), San José.

[32] Powell, G. and Bjork, R. (1995) Buffon's Macaw: Some Observations on the Costa Rican Populations, Its Lowland Forest Habitat and Conservation. Rare Center for Tropical Conservation, Monteverde.

[33] Juniper, T. and Parr, M. (1998) Parrots: A Guide to the Parrots of the World. Pica Press, Robertsbridge.

[34] Zuchowsky, W. (2007) Tropical Plants of Costa Rica. Cornell University Press, New York.

[35] UNEP (2010) Convention on International Trade in Endangered Species of Wild Fauna and Flora (CITES). Appendices I, II and III. United Nations Environment Programme (UNEP), Geneva.

[36] Garzuglia, M. (2006) Global Forest Resources Assessment 2005. Threatened, Endangered and Vulnerable Tree Species: A Comparison between FRA 2005 and the ICUN Red List. Forest Resources Assessment (FRA) of the Food and Agriculture Organization (FAO), Rome.

[37] Canet-Desanti, L. (2007) Herramientas Para el Diseño, Gestión y Monitoreo de Corredores Biológicos en Costa Rica. MSc Dissertation, Centro Agronómico Tropical de Investigación y Enseñanza (CATIE), Turrialba.

[38] CREAF: Centre de Recerca Ecològica i Aplicacions Forestals (2000) MiraMon. http://www.creaf.uab.es/miramon/index.htm

[39] Pons, X. and Masó, J. (2000) MiraMon Map Reader, a New Way for Distributing and Exploring Geographic Information. http://www.creaf.uab.es/MiraMon/publicat/papers/isprs00/mmr.htm

[40] Santos-Preciado, J.M. (2004) Sistemas de Información Geográfica: Unidades Didácticas. Universidad Nacional de Educación a Distancia (UNED), Madrid.

[41] Brenes, D., Figueroa, A. and Ruiz, A. (2009) Informe de Revisión de Nidos de Lapas (Temporada 2009). Campaña Binacional de la Lapa Verde (Ara ambiguus) en el Corredor Biológico Binacional el Castillo, San Juan, La Selva. CCT, San José.

[42] Gómez-Figueroa, P. (2009) Ecología y Conservación de la Lapa Verde (Ara ambigua) en Costa Rica. Posgrado y Sociedad, 9, 58-80.

[43] Kleinn, C., Ramírez, C., Chávez, D. and Lobo, S. (2001) Estudio Piloto para el Inventario Forestal Nacional en Costa Rica, Final Assessment Report. FRA/FAO, Rome.

[44] Wessa, P. (2011) Free Statistics Software of the Office for Research Development and Education. Version 1.1.23-r7. http://www.wessa.net/

[45] Mijal, M. (2001) Ara macao. Animal Diversity Web (ADW). http://animaldiversity.ummz.umich.edu/accounts/Ara_macao/\#predation

[46] Begotti, R.A. and Filho, A.M. (2012) Fatal Attack on an Adult Chestnut-Fronted Macaw Ara severus by a Boa Constrictor in the Brazilian Amazon. Cotinga, 34, 106-107.

[47] Bernard, H.R. (2006) Research Methods in Anthropology. Qualitative and Quantitative Approaches. Altamira Press, Lanham.

[48] Levesque, R. (2007) Programming and Data Management for SPSS Statistics 17.0: A Guide for SPSS Statistics and SAS Users. SPSS, Chicago.

[49] Olah, G., Vigo, G., Heinsohn, R. and Brightsmith, D.J. (2014) Nest Site Selection and Efficacy of Artificial Nests for Breeding Success of Scarlet Macaws Ara macao macao in Lowland Peru. Journal for Nature Conservation, 22, 176185. http://dx.doi.org/10.1016/j.jnc.2013.11.003

[50] Vaughan, C., Bremer, M. and Dear, F. (2009) Scarlet Macaw Ara macao (Psitaciformes: Psittacidae) Parental Nest Visitation in Costa Rica: Implications for Research and Conservation. Revista de Biología Tropical, 57, 395-400.

[51] Stiles, G. and Skutch, A. (1989) Guía de Aves de Costa Rica. Cornell University Press, New York.

[52] Collar, N.J. (2006) Parrot Reintroduction: Towards a Synthesis of Best Practice. Proceedings of the 6th International Parrot Convention, Tenerife, 27-30 September 2006, 82-107. 
[53] Seddon, P.J., Armstrong, D.P. and Maloney, R.F. (2006) Developing the Science of Reintroduction Biology. Conservation Biology, 21, 303-312. http://dx.doi.org/10.1111/j.1523-1739.2006.00627.x

[54] Estrada, J. (2014) Finding Correlations among Successful Reintroduction Programs: An Analysis and Review of Current and Past Mistakes. MSc Practicum, University of Michigan, Ann Arbor.

[55] Rabinowitz, D., Cairns, S. and Dilon, T. (1986) Conservation Biology: The Science of Scarcity and Diversity. Sinauer Associates Inc., Sunderland.

[56] Chaverri, I. (1996) Elaboración de los Mapas Preliminares de Población de Dipteryx panamensis (Pittier) en la Cureña, Región Huetar Norte, Costa Rica. Instituto Tecnológico de Costa Rica (ITCR), San José.

[57] COSEFORMA (1999) Almendro en la Zona Norte de Costa Rica. Cooperación en los Sectores Forestal y Maderero, San José.

[58] Monge-Arias, G., Chassot, O., Chavés, H., Rodríguez, J.E., Gutiérrez-Espeleta, G., Traylor-Holzer, K. and Matamoros, Y. (2009) Taller de Conservación de la Guacamaya Verde (Ara ambiguus). Evaluación de Viabilidad Poblacional y de Hábitat (PVA). CCT, San José.

[59] Vaughan, C., Nemeth, N.M., Cary, J. and Temple, S. (2005) Response of a Scarlet Macaw Ara macao Population to Conservation Practices in Costa Rica. Bird Conservation International, 15, 119-130. http://dx.doi.org/10.1017/S0959270905000092

[60] Butler, P.J. (1992) Parrots, Pressures, People, and Pride. In: Beissinger, S.R. and Snyder, N.F.R., Eds., New World Parrots in Crisis: Solutions from Conservation Biology, Smithsonian Institution Press, Washington DC, 25-46. 
Scientific Research Publishing (SCIRP) is one of the largest Open Access journal publishers. It is currently publishing more than 200 open access, online, peer-reviewed journals covering a wide range of academic disciplines. SCIRP serves the worldwide academic communities and contributes to the progress and application of science with its publication.

Other selected journals from SCIRP are listed as below. Submit your manuscript to us via either submit@scirp.org or Online Submission Portal.
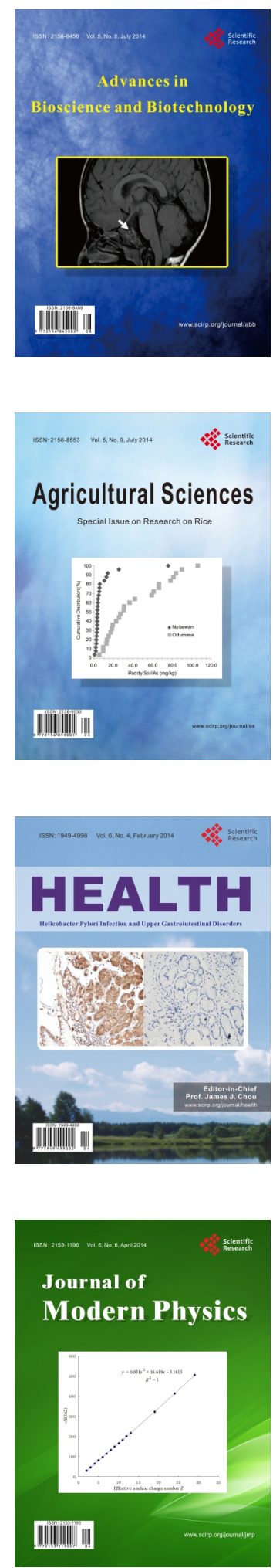
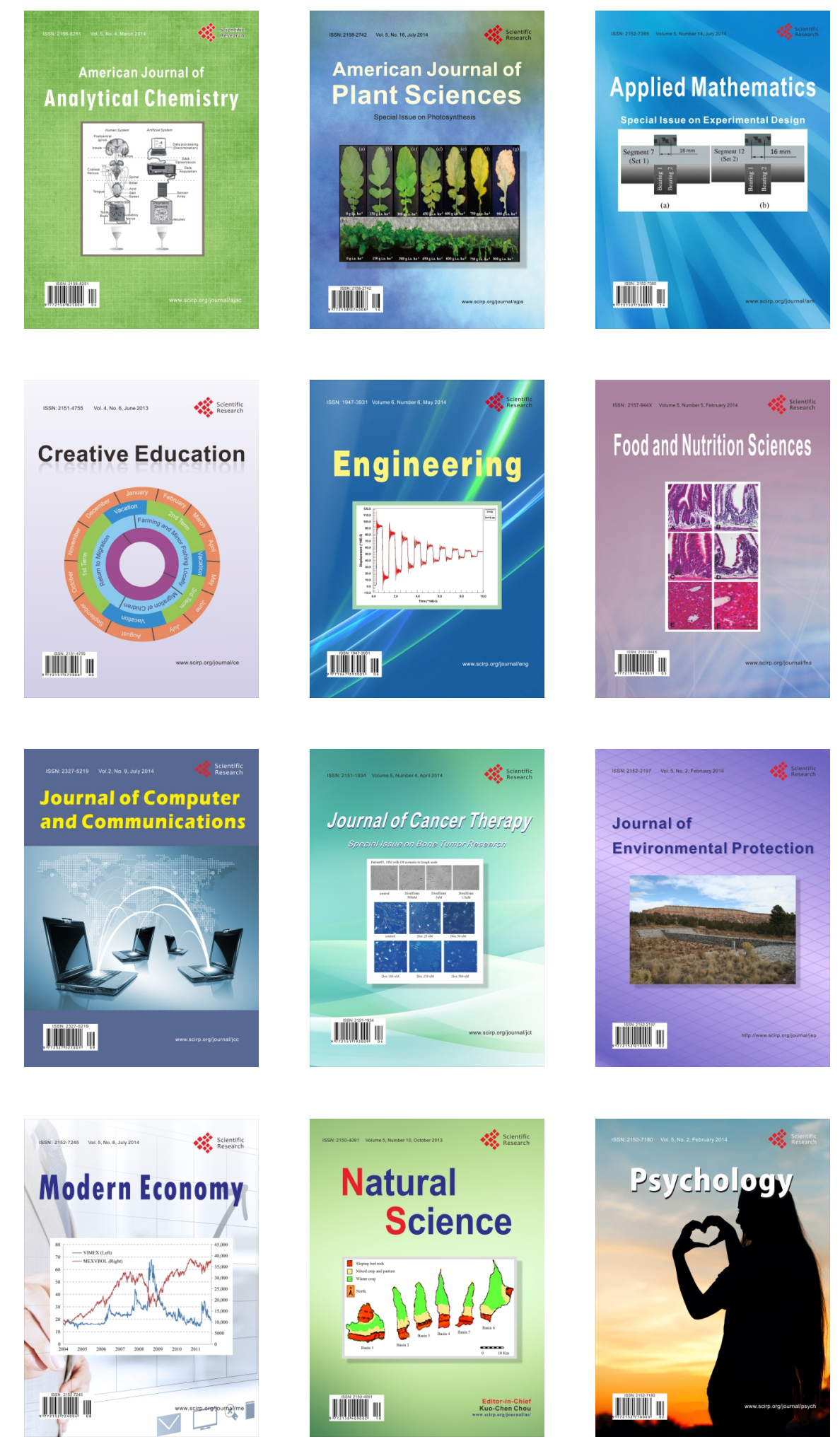